\title{
PKM Peningkatan Perekonomian Rumah Tangga Melalui Usaha Kerajinan Lidi
}

\author{
Riski Martini ${ }^{*}$, Putra Manuaba² ${ }^{2}$ Anggita Wahyudi ${ }^{3}$ (iD \\ 1,2,3 Universitas Warmadewa, Indonesia \\ *Corresponding author: riskimartini@gmail.com
}

\begin{abstract}
Program pemberdayaan masyarakat sudah dilakukan pemerintah dan sesuai dengan tujuan pembangunan Indonesia seutuhnya. Pembangunan menempatkan manusia sebagai subjek pembangunan. Pemberdayaan usaha sangat menunjang ekonomi rumah tangga, salah satunya adalah usaha kerajinan lidi. Bahan baku pembuatan kerajinan lidi adalah lidi daun kelapa, yang merupakan salah satu bagian yang dihasilkan dari pohon kelapa. Salah satu produk olahan dari lidi adalah piring lidi, piring lidi semacam piring alas yang terbuat dari lidi daun kelapa/daun lontar/lidi kelapa sawit yang telah diproses hingga halus dan dirangkai menyerupai piring makan. Perubahan pola hidup/budaya masyarakat yang menginginkan hal yang lebih praktis, terutama untuk kegiatan pesta, bila dulunya menggunakan piring yang terbuat kaca maka sekarang berubah lebih memilih menggunakan piring yang terbuat dari lidi atau rotan. Hal ini dilakukan dengan pertimbangan bahwa bila menggunakan piring yang terbuat dari kaca akan memerlukan tenaga, serta memerlukan air dan sabun untuk mencucinya sedangkan dengan menggunakan piring lidi cukup dialasi daun pisang atau kertas makanan, tanpa harus mencuci. Khalayak sasaran dari program pengabdian masyarakan ini adalah Ibu Ni Luh Suparningsih yang berasal dari Buleleng dan saat ini tinggal di Jalan Astasura Denpasar. Kontribusi dasar dari program ini adalah meningkatkan kemampuan pembukuan, kapasitas produksi, peningkatan pemasaran melalui website, dan mengembangkan diversifikasi produk.
\end{abstract}

Keywords: Usaha Kerajinan Lidi, Rumah Tangga

\section{Abstract}

The community empowerment program has been carried out by the government and is in accordance with Indonesia's development goals as a whole, so development must be a social change that does not only occur in the standard of life of the community but also on the role of the elements in it. Development places humans as the subject of development. Empowerment of businesses really supports the household economy, one of which is the stick craft business. The raw material for making stick crafts is the coconut leaf stick, which is one part of the coconut tree. One of the products of sticky waste that is produced is a stick plate, a stick plate like a plate made of coconut leaf sticks / palm leaves / palm oil sticks that have been processed until they are smooth and assembled to resemble a dinner plate. Changes in the lifestyle / culture of the people who want things that are more practical, especially for party activities, if they used to use plates made of glass, they now prefer to use plates made of sticks or rattan. This is done with the consideration that when using a plate made of glass it will require energy to wash it as well as to clean it requires water and soap, while using a stick plate it is enough to cover it with banana leaves or food paper after using the leftover dish mat without having to wash the dishes. The target audience for this community service program is Mrs. Ni Luh Suparningsih who comes from Buleleng and currently lives on Jalan Astasura Denpasar. The basic contribution of this program is to improve bookkeeping capabilities, production capacity, increase marketing through the website, and develop product diversification.

Keywords: Stick Craft Business, household

\begin{tabular}{|c|c|c|}
\hline History: & & Publisher: Undiksha Press \\
\hline Received & : 02 August 2020 & Licensed: This work is licensed under \\
\hline Revised & : 09 September 2020 & a Creative Commons Attribution 3.0 License \\
\hline Accepted & : 06 October 2020 & (c) (†) () \\
\hline Published & : 30 November 2020 & ${ }_{E Y} S_{A}$ \\
\hline
\end{tabular}




\section{Introduction}

Kerajinan dapat diartikan dengan kecakapan melaksanakan, mengolah, dan menciptakan, benda. Kerajinan tangan merupakan aktivitas berkesenian dalam dunia Pendidikan (Ismayati \& Mastiah, 2017). Istilah. Jenis benda ini bermacam ragam, namun umumnya para ahli mengkategorikan dalam dua bagian, yakni benda kerajinan untuk hiasan dan benda kerajinan praktis. Sumanto \& Sukamti (2018) Keberadaan pembuatan aneka ragam model atau bentuk benda kerajinan tangan tersebut tidak lepas dari dorongan keinginan dan kebutuhan dalam kehidupan manusia. Kerajinan tangan merupakan suatu produk hasil keterampilan manusia berupa hiasan, benda seni ataupun barang pakai untuk memenuhi kebutuhan manusia. Untuk membuat sebuah kerajinan tangan diperlukan suatu keterampilan. Pengrajin memperoleh keterampilan dengan cara belajar melalui orang lain maupun melalui pengalaman diri sendiri. Dengan memiliki keterampilan pengrajin akan dapat bertahan hidup dalam lingkungan yang selalu berubah. Menurut Raharjo (2011) bahwa jenis seni kerajinan diklasifikasikan berdasarkan dari segi teknis dan paling populer meliputi: seni ukir, seni keramik, seni anyam, seni tenun, dan seni batik. Kerajinan/ kria adalah jenis karya seni rupa terapan (seni pakai) yang umumnya dihasilkan melalui kerja terampil para perajinnya Sumanto (2011). Banyak keterampilan yang produktif salah satunya yaitu keterampilan yang berupa seni rupa terapan. Pada proses pembelajaran keterampilan yang produktif bisa kita sesuaikan dengan kebutuhan yang tinggi pada saat itu disekitar wilayah tersebut Azzahra \& Hasan (2018).

Bahan baku pembuatan kerajinan lidi adalah lidi daun kelapa merupakan salah satu bagian yang dihasilkan oleh pohon kelapa. Lidi daun kelapa memiliki banyak manfaat selain sering dibuat sapu lidi, lidi daun kelapa juga bisa dimanfaatkan untuk kebutuhan rumah tangga lainnya seperti piring lidi, keranjang buah dari lidi, vas dari lidi dan lain-lain. Salah satu produk olahan limbah lidi yang dihasilkan adalah piring lidi, piring lidi semacam piring alas yang terbuat dari lidi daun kelapa/daun lontar/lidi kelapa sawit yang telah diproses hingga halus dan dirangkai menyerupai piring makan Budiywono et al., (2018).

Perubahan pola hidup/budaya masyarakat yang menginginkan hal yang lebih praktis, terutama untuk kegiatan pesta, bila dulunya menggunakan piring yang terbuat dari kaca maka sekarang berubah lebih memilih menggunakan piring yang terbuat dari lidi atau rotan yang dianyam Patria et al., (2015). Hal ini dilakukan dengan pertimbangan bahwa bila menggunakan piring yang terbuat dari kaca akan memerlukan tenaga untuk mencucinya demikian pula untuk membersihkannya membutuhkan air yang banyak dan sabun sedangkan dengan menggunakan piring lidi cukup dialasi daun pisang atau kertas makanan setelah dipakai alas piring sisa dibuang tanpa harus mencuci, selain hemat tenaga kita juga menghemat penggunaan air (Madonna et al., 2014).

Lidi merupakan bahan utama dalam pembuatan piring lidi. Lidi harus memiliki kelenturan yang sama dengan panjang yang kurang lebih sama agar dapat dianyam dengan baik. Pemilihan lidi yang memiliki kelenturan yang sama dapat dilakukan dengan memegang sejumput lidi pada bagian ujung lalu ujung lidi diangkat maka akan terlihat lidi yang jatuh akibat gravitasi dan lidi yang tidak jatuh (kaku) tidak memiliki kelenturan yang sama dengan lidi lainnya Pariyanti et al., (2020). Lidi yang biasanya hanya digunakan sebagai sapu akan memiliki nilai tambah saat mampu dimanfaatkan sebagai bahan kerajinan tangan, kerajinan tangan dari lidi ini juga merupakan salah satu kerajinan accessories Rahardjo (2016), sehingga mempunyai nilai jual yang cukup tinggi di masyarakat Adnani et al., (2019). Dalam membuat anyaman lidi memerlukan keterampilan dasar dan kreatifitas untuk bentukbentuk yang lain menjadi produk yang layak jual. Setelah terampil menghasilkan produk anyaman lidi tersebut, perlu lagi pengetahuan untuk pemasaran produk sehingga diperoleh strategi dan perhitungan yang tepat secara ekonomis sehingga kerajinan anyaman lidi 
menjadi sumber pendapatan bagi masyarakat desa. Seperti yang dilaksanakn oleh Irianti et al., (2019) dimana masyarakat di Desa Sepahat mampu membuat anyaman lidi sawit dengan berbagai macam bentuk seperti piring, mangkok, tempat buah, dan lain sebagainya.Terbentuknya satu kelompok pengrajin anyaman lidi sawit yang akan berfungsi sebagai wadah pengembangan produksi dan pemasaran anyaman lidi sawit di Desa Sepahat. Dampak dari pelatihan tersebut telah memberikan kontribusi pendapatan ibu-ibu PKK sekitar Rp 1.000.000-Rp1.500.000 per bulan.

Oleh karena itu tujuan dari pengabdian ini adalah untuk mengetahui pemanfaatan lidi kelapa sebagai bahan untuk membuat piring lidi dan melakukan pelatihan dalam hal pencatatan keuangan dan pemasaran sehingga dapat menambah penghasilan sekaligus sebagai lapangan kerja/usaha baru bagi mereka. Masyarakat yang menjadi sasaran kegiatan kerajinan anyaman lidi ini adalah Ibu Ni Luh Suparningsih yang berasal dari Buleleng dan saat ini tinggal di Jalan Astasura Denpasar.

Ibu Ni Luh Suparningsih berasal dari keluarga yang menekuni usaha kerajinan anyaman lidi, sehingga sejak duduk di bangku sekolah dasar beliau sudah mampu membuat kerajinan lidi. Berbekal keterampilan yang dimiliki tersebut saat beliau merantau ke Denpasar beliau mengajak sanak keluarga dan kerabat untuk menekuni kembali usaha kerajinan lidi tersebut, dan dengan dibantu kerabat beliau memulai usaha dengan memasarkan hasil karya beliau di pasar tradisional dan dari mulut ke mulut. Saat ini beliau bekerja sama dengan belasan pengrajin lidi baik itu lidi kelapa dan lidi lontar yang berada di wilayah Buleleng. Kerajinan yang beliau buat mulai dari piring makan, piring kue, piring sodan, nampan, keranjang buah dan berbagai jenis dan bentuk kerajinan lidi sesuai pesanan.

Berkaitan dengan pengelolaan manajemen usaha pembuatan kerajinan lidi Ibu Ni Luh Suparningsih ini, maka dapat dideskripsikan kondisi dari usaha tersebut adalah sebagai berikut: 1) Manajemen pengelolaan usaha pembuatan janur kerajinan lidi Ibu Ni Luh Suparningsih belum dilakukan secara professional karena dikelola secara kekeluargaan dan kurang pemahaman terhadap tata kelola perusahaan terutama berkaitan dengan strategi produksi dan pemasaran; 2) Ibu Ni Luh Suparningsih tidak memiliki pembukuan/catatan harian terkait produksi, pendapatan, biaya, laba rugi, sehingga benar-benar tidak mengatahui dengan jelas kondisi dan posisi keuangan usahanya; 3) Usaha pembuatan kerajinan lidi Ibu Ni Luh Suparningsih belum memiliki model pemasaran untuk mempromosikan hasil usahanya. Selama ini hanya melakukan pengiklanan via facebook tanpa ada pemasangan foto hasil usaha 4) Desain yang dibuat untuk kerajinan lidi masih bisa dikembangkan sehingga menghasilkan hiasan lidi yang memiliki lebih beragam bentuk.

Berdasarkan hasil observasi yang dilakukan pada usaha pembuatan kerajinan lidi Ibu Ni Luh Suparningsih, terdapat beberapa permasalahan yang menjadi kendala dalam memajukan dan mengembangkan usahanya dari sisi produksi dan manajemen. Permasalahan tersebut adalah sebagai berikut: a) Belum memiliki pembukuan atau catatan terkait pendapatan, pengeluaran, biaya produksi dan laba ruginya, b) Belum memahami tata kelola perusahaan terutama dalam hal menentukan strategi produksi dan pemasaran, c) Belum memiliki sistem pemasaran yang baik, d) Model kerajinan lidi yang dihasilkan kurang bervariasi. Dari permasalahan yang dihadapi, maka solusi penyelesaian masalah yang ditawarkan adalah sebagai berikut: 1) Melakukan pendampingan dan membantu dalam pembuatan pembukuan dan laporan keuangan sederhana serta memberikan pelatihan mengenai tata cara pembuatan pembukuan dan pelaporan keuangan sederhana. Pendampingan dan pelatihan ini diharapkan dapat memberikan manfaat ekonomi di masa depan bagi pengembangan usaha kerajinan lidi Ibu Ni Luh Suparningsih. 2) Memberikan pelatihan mengenai penerapan tata kelola perusahaan terutama berkaitan dengan penentuan strategi produksi maupun pemasaran. 3) Membuatkan website dan sosial media (facebook dan Instagram) untuk membantu dalam pemasaran produk serta melakukan pendampingan 
dalam penggunaannya. Dan 4) Melakukan pendampingan dan membantu dalam pengembangan desain produk yang dihasilkan sehingga mampu menghasilkan produk yang lebih bervariasi.

Beberapa penelitian yang relevan untuk pengabdian ini, seperti penelitian yang dilaksanakan oleh Nainggolan \& Taime (2017) dimana usaha anyaman lidi di Kabupaten Mimika dinyatakan layak untuk dilaksanakan. Hasil usaha yang bersangkutan sudah layak secara non finansial. Penelitian yang dilaksanakan oleh Irianti et al., (2019) di mana dampak dari pelatihan yang dilaksanakn oleh Irianti dkk, telah memberikan kontribusi pendapatan ibu-ibu PKK sekitar Rp 1.000.000-Rp1.500.000 per bulan. Penelitian lainnya yang serupa adalah penelitian yang dilaksanakan oleh Suwardi \& Saumi (2018) namun bahan yang digunakan dalam penelitian berbeda karena bahan yang digunakan adalah lidi dari daun kelapa sawit, hasil kegiatan pelatihan dan pendampingan bagi kelompok perempuan Karya Muda dapat disimpulkan bahwa kelompok perempuan Karya Muda telah berhasil memproduksi aneka produk kerajinan tenun dari limbah lidi kelapa sawit dengan menggunakan ATBM seperti kotak tisu, tas laptop, kotak pensil, sajadah, dan lain-lain. Dapat dilihat dari peatihan yang telah dilakukan banyak produk yang dihasilkan dari limbah lidi kelapa sawit.

Tujuan program pengabdian ini adalah untuk membantu mitra dalam hal ini adalah pengusaha pembuat kerajinan lidi Ibu Ni Luh Suparningsih untuk mengatasi permasalah yang dihadapi berkaitan dengan pengembangan usahanya. Perbedaan pengabdian ini dengan pengabdian lainnya adalah, pada pengabdian ini banyak solusi yang diberikan kepada Ibu Ni Luh Suparningsih terkait dengan kerajinan piring lidi, dimana masalah yang dihadapi oleh Ibu Ni Luh Suparningsih cukup banyak. Sehingga pada pengabdian ini akan emmberikan banyak solusi yang dibutuhkan oleh mitra yaitu Ibu Ni Luh Suparningsih.

\section{Materials and Methods}

Berdasarkan identifikasi permasalahan yang dihadapi mitra dan solusi yang ditawarkan, maka metode pelaksanaan kegiatan. Melakukan pendampingan dan membantu dalam pembuatan pembukuan dan laporan keuangan sederhana serta memberikan pelatihan mengenai tata cara pembuatan pembukuan dan pelaporan keuangan sederhana. Pendampingan dan pelatihan ini diharapkan dapat memberikan manfaat ekonomi di masa depan bagi pengembangan usaha pembuatan kerajinan lidi Ibu Ni Luh Suparningsih. Memberikan pelatihan mengenai penerapan tata kelola perusahaan terutama berkaitan dengan penentuan strategi produksi maupun pemasaran. Membuatkan website dan sosial media (facebook dan Instagram) untuk membantu dalam pemasaran produk serta melakukan pendampingan dalam penggunaannya. Melakukan pendampingan dan mebantu dalam pengembangan desain produk yang dihasilkan sehingga mampu menghasilkan produk yang lebih bervariasi

\section{Results and Discussion}

Berdasarkan permasalahan yang akan diselesaikan pada masing-masing mitra, maka hal-hal yang akan dilakukan selama kegiatan meliputi: a) Pendampingan dan membantu dalam pembuatan pembukuan dan laporan keuangan sederhana, b) Pelatihan penerapan tata kelola perusahaan, c) Pelatihan dalam membuat sistem pemasaran produk, d) Pelatihan pembuatan design. Dalam hal ini senada dengan penelitian dari (Rahardjo, 2016) Dimana melalui kegiatan pengabdian kepada masyarakat ini diharapkan akan memberikan ketrampilan yang dapat dimanfaatkan untuk mencari tambahan pendapatan.

Berikut ini capaian pelaksanaan kegiatan sesuai dengan yang diprioritaskan pada masing-masing mitra, yaitu 
1. Pemberian pendampingan dan pelatihan pembukuan sederhana, menjelaskan pencatatan sederhana bagaimana cara mencatat biaya-biaya produksi dan mencatat penjualan. Memisahkan keuangan prbadi dengan keuangan hasil usaha sekaligus pelatihan penerapan tata kelola perusahaan. Ditunjukkan pada gambar 1 berikut.
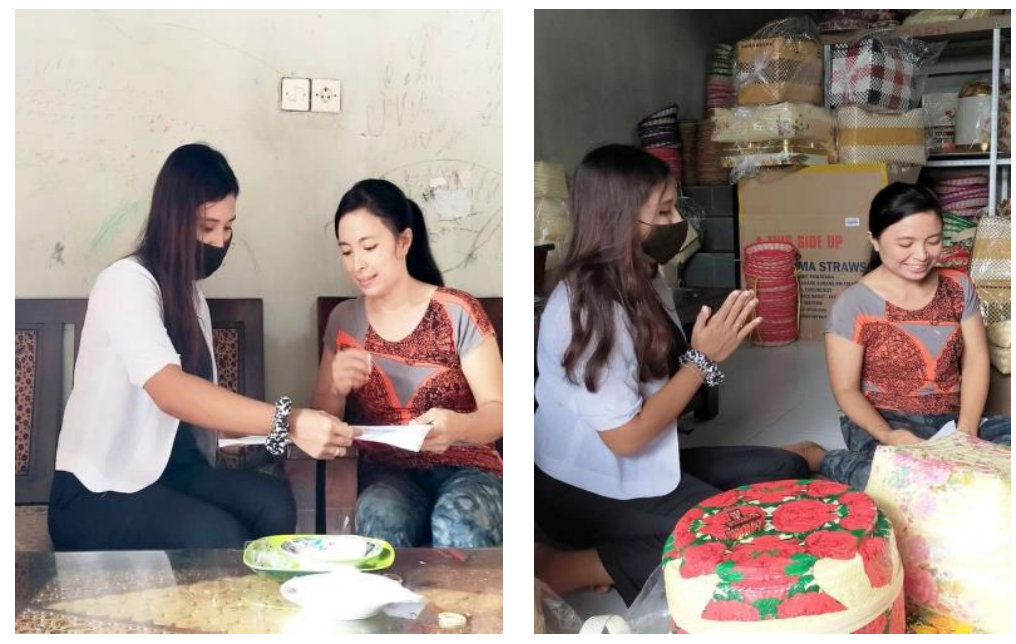

Gambar 1. Pendampingan Pelatihan Pembukuan

2. Pelatihan penerapan tata kelola perusahaan, penerapan tata kelola perusahaan (corporate governance) dalam sebuah perusahaan sangat penting sebagai salah satu proses untuk menjaga kesinambungan usaha perusahaan dalam jangka panjang hal ini dilakukan dengan memberikan pelatihan bagaimana menentukan strategi produksi dan strategi pemasaran yang tepat dan juga mengelola agar tenaga pekerja yang dimiliki dapat bekerja secara maksimal.

3. Pembuatan website untuk mitra yang bertujuan untuk memperluas segmentasi pasar dan akun media sosial seperti facebook dan instagram agar produk usaha mitra dapat dikenal luas di masyarakat.

4. Pelatihan pembuatan design produk untuk usaha janur berupa pengembangan design ingka, yaitu tidak hanya sebagai ingka makan namun juga sebagai dekorasi rumah tangga dari janur. Selain itu terdapat pengembangan usaha yang dilakukan yaitu pembuatan usaha kerajinan dari bamboo berupa keben. Adapun jenis design ingka yang ditawarkan, di tujukkan pada gambar 2 berikut.
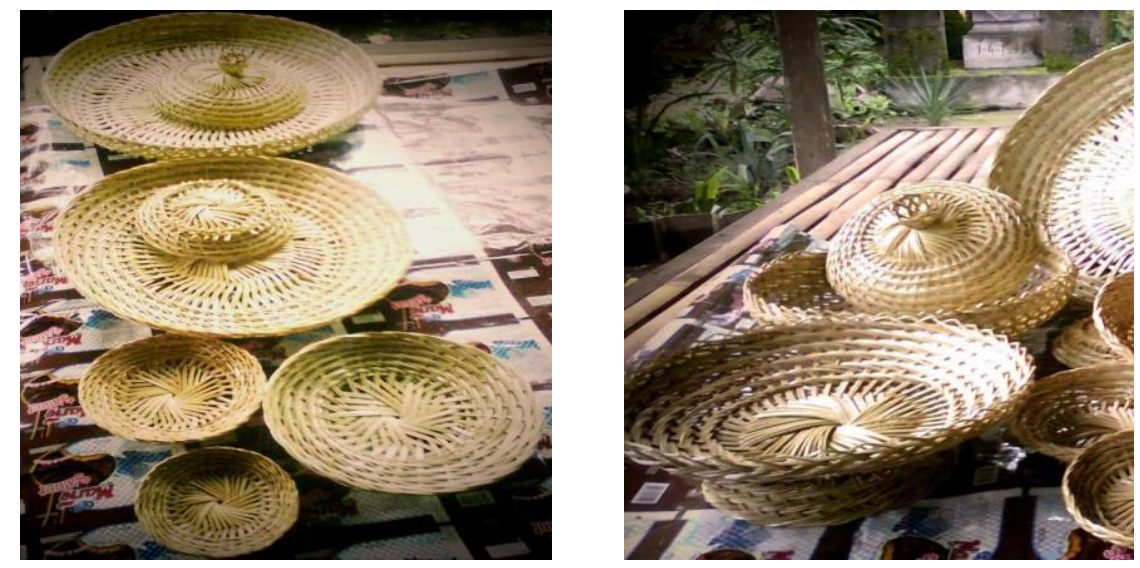

Gambar 2. Hasil Produk 
Setelah diberikan pelatihan, pengaruh dari pelatihan yang diberikan kepada masingmasing mintra adalah sabagai berikut:

\section{Pembuatan Buku Laporan Keuangan Sederhana}

Pendekatan ini menekankan para mitra untuk dapat membuat sebuah buku laporan keuangan sederhana. Mitra di dampingi oleh tim pengusul (ketua pengusul) untuk menyusun buku laporan keuangan sederhana. Mitra akan dibimbing dan didampingi untuk mencatat setiap hal yang berkaitan dengan pengeluaran biaya dan pemasukandalam proses produksi dan pemasaran hiasan janur termasuk besarnya upah yang harus dibayarkan kepada tenaga kerjanya. Mitra diharapkan nantinya dapat membuat laporan keuangan sederhana, dapat mengetahui berapa besarnya biaya yang dihabiskan dalam proses pembuatan hiasan janur, bisa menentukan harga jual dan besarnya upah yang harus dibayarkan kepada tenaga kerjanya. Dengan pemahaman yang diberikan diharapkan nantinya kelangsungan usaha mitra dapat berjalan lancar dan berkembang. Pencatatan biaya-biaya produksi terlihat jelas dan hasil dari penjualan terlihat jelas melalui catatan. Sehingga keuangan hasil usaha dapat terlihat jelas dan tidak tercampur dengan keuangan pribadi.

Pelaksanaan program ini dilakukan melalui pendekatan individual (Kurniati, 2013). Pendekatan individual ini diawali dengan menggali pemahaman mitra berkaitan dengan pembukuan. Setelah menggali pemahaman mitra mengenai pembukuan, kemudian dilanjutkan dengan memberikan materi dan pemahaman seperti apa bentuk dari buku keuangan sederhana serta apa saja isi dari buku keuangan sederhana. Kemudian, mitra diajak mencari tahu hal apa saja yang dibutuhkan jika ingin mengetahui berapa laba bersih yang dihasilkan dan berapa besar riilnya biaya yang dihabiskan serta membuat buku laporan keuangan sederhana. Setelah memberikan pemahaman, mitra kemudian diberikan sebuah buku kosong untuk diajak menyusun buku laporan keuangan sederhana.

\section{Pelatihan Penerapan Tata Kelola Perusahaan}

Mitra belum memahami tata kelola perusahaan terutama dalam hal menentukan strategi produksi dan pemasaran. Untuk mengatasi permasalahan tersebut, tim pengusul (anggota) akan membantu dalam memberikan penyuluhan tentang penerapan tata kelola perusahaan. Tim pengusul (anggota) akan memberikan penjelasan dan pendampingan dalam menentukan strategi produksi dan strategi pemasaran. Tim pengusul (anggota) juga akan memberikan penyuluhan bagaimana caranya agar tenaga kerja yang dimiliki oleh mitra mau bekerja maksimal lagi. Dengan adanya bantuan ini diharapkan nantinya mitra dapat menerapkan strategi yang tepat untuk usahanya sehingga usahanya dapat berkembang dan hasilnya lebih maksimal lagi. Strategi produksi dilaksanakan dengan tepat dan strategi pemasaran yang tepat sehingga hasil dari pemasaran menjadi meningkat. Tenaga kerja dikelola dengan baik sehingga tenaga kerja bisa bekerja dengan maksimal.

\section{Pelatihan Dalam Membuat Sistem Pemasaran Produk}

Membantu mitra dalam memasarkan hasil produksinya, dimana selama ini mitra hanya mengandalkan pelanggan tetapnya saja dalam memasarkan hasil produksinya. Berdasarkan pendekatan individual yang dilakukan diketahui bahwa mitra merupakan orang yang tidak paham tentang teknologi informasi serta tidak tahu bagaimana cara memanfaatkan teknologi informasi tersebut. Oleh karena itu tim pengusul (anggota) akan memberikan pelatihan tentang strategi pemasaran, membantu dalam membuatkan website dan akun media sosial seperti facebook dan instagram serta melakukan pendampingan dalam penggunaannya. Diharapkan nantinya dengan penggunaan website dan media sosial tersebut mitra dapat memperluas pemasaran produknya (Annysa \& Putri, 2018). Melalui website segmentasi 
pasar menjadi meluan dan akun media sosial seperti facebook dan instagram juga sangat berpengaruh mengungat cukup banya masyarakat yang menggunakan aplikasi facebook dan Instagram sehingga produk usaha mitra dapat dkenal luas dimasyarakat.

\section{Pelatihan Pembuatan Desain}

Berdasarkan hasil survei lapangan diketahui bahwa mitra hanya menghasilkan produk kerajinan lidi berupa piring makan, piring kue, piring sodan, nampan, keranjang buah dan berbagai jenis dan bentuk kerajinan lidi sesuai pesanan. Setelah dilakukan pelatihan diharapkan mitra dapat menyediakan produk olahan lidi yang lebih beragam dan memiliki desain yang menarik agar mudah diingat oleh pemesan (Juniawa et al., 2019). Pekatihan pembuatan berbagai design ingka membuat daya jual kerajinan anyam dari lidi memiliki daya jual yang tinggi, sehingga hal ini akan cukup diminati oleh masyarakat.

\section{Conclusion}

Berdasarkan atas kegiatan yang telah dilaksanakan, dapat disimpulkan bahwa terdapat beberapa permasalahan yang menjadi kendala dalam memajukan dan mengembangkan usahanya. Permasalah tersebut adalah sebagai berikut: a) Belum memiliki pembukuan atau catatan terkait pendapatan, pengeluaran, biaya produksi dan laba ruginya. b) Belum memahami tata kelola perusahaan terutama dalam hal menentukan strategi produksi dan pemasaran, c) Belum memiliki sistem pemasaran seperti website, d) Model dari hiasan janur yang dihasilkan kurang bervariasi. Pelaksanaan pengabdian ini diharapkan dapat menyasar mitra lain dengan usaha sejenis, sehingga melakukan pengembangan potensi usaha yang tinggi, perlu bagi mitra untuk memiliki kompetensi yang memadai. Selain dari bidang keuangan dan pemasaran, para mitra juga peru diberikan penyuluhan dari segi aspek hukum terutama mengenai ijin usaha dan paten produk.

\section{References}

Adnani, L., Kania, T. N., Ilmu, P., \& Bisnis, A. (2019). Strategi pengembangan usaha piring lidi didesa cibadak kecamatan banjarsari kabupaten ciamis. Business Preneur: Jurnal Ilmu Administrasi Bisnis, 1(1), 49-63. unpas.ac.id

Annysa, E., \& Putri, P. (2018). Pelatihan Pemasaran, Pemberdayaan Toko Online, Dan Pengenalan M-Commerce Pada Produk Unggulan Jagung Tortila Di Kecamatan Trucuk Kabupaten Bojonegoro. Jurnal Pengabdian Masyarakat, 1(2), 56-66. jurnal.um-tapsel.ac.id

Azzahra, F., \& Hasan, Y. (2018). Meningkatkan Keterampilan membuat Piring Anyaman Lidi melalui Strategi Joyful Learning bagi Anak Tunagrahita Ringan. Penelitian Pendidikan Kebutuhan Khusus, 6(2006), 200-205. ejournal.unp.ac.id/index.php/jupekhu

Budiywono, E., Islam, A., \& Blokagung, D. (2018). Pemanfaatan Lidi Daun Kelapa Menjadi Handycraft Dalam Bentuk Anyaman Piring Lidi di Desa Purwoasri Kecamatan Tegaldlimo Kabupaten Banyuwangi. Jurnal Pengabdian Kepada Masyarakat, I, 1120. ejournal.iaida.ac.id

Irianti, M., Syahza, A., Asmit, B., Bakce, D., Tampubulon, D., Fakultas, D., \& Universitas, P. (2019). Peningkatan pendapatan masyarakat melalui pemanfaatan limbah lidi kelapa sawit didesa sepahat kabupaten bengkalis. Prosiding Seminar Hasil Pengabdian Kepada Masyarakat, 9.

Ismayati J.S, S., \& Mastiah. (2017). Upaya meningkatkan keterampilan kerajinan tangan menggunakan metode demonstrasi teknik. Pendidikan Dasar, 5(1), 56-64. 
https://doi.org/10.46368/jpd.v5i1.129

Juniawa, F. P., Sujono, Hamidah, \& Syifania, D. Y. (2019). Pelatihan Desain Kemasan Bagi UKM Rumah Tangga di Bangka Barat. Seminar Nasional Hasil Pengabdian Kepada Masyarakat 2019. media.neliti.com

Kurniati, A. (2013). Aplikasi Pendekatan Pembelajaran Individual Mata Pelajaran Pendidikan Kewarganegaraan Pada Siswa Difabel ( Tunanetra) di MAN Maguwoharjo. Citizenship, 3(20), 41-56. journal.uad.ac.id

Madonna, S., Studi, P., Lingkungan, T., \& Bakrie, U. (2014). Efisiensi Energi Melalui Penghematan Penggunaan Air ( Studi Kasus : Institusi Pendidikan Tinggi Universitas Bakrie ). Teknik Sipil, 12(4), 267-274. media.neliti.com

Nainggolan, F., \& Taime, H. (2017). Analisis Kelayakan Usaha Anyaman Lidi di Kabupaten Mimika (Studi Kasus Pada Usaha Kerajinan Tangan Masyarakat Nawaripi). Jurnal Kritis, I, 1-13. ejournal.stiejb.ac.id

Pariyanti, E., Buchori, \& Rinnanik. (2020). Pemberdayaan dan Peningkatan Pendapatan Ibu Rumahtangga Melalui Pembuatan Berbagai Produk dari Bahan Dasar Lidi. Jurnal Pengabdian KITA, 01(01). http://ojs.umb-bungo.ac.id/index.php/PKITA/index\%0D

Patria, A. S., Mutmaniah, S., Pendidikan, J., Rupa, S., \& Surabaya, U. N. (2015). Kerajinan anyam sebagai pelestarian kearifan lokal. Jurnal Dimensi Seni Rupa Dan Desain, 12(1), 1-10. trijurnal.lemlit.trisakti.ac.id

Rahardjo, E. T. (2016). Ketrampilan Kerajinan Accessories Untuk Modal Kewirausahaan Drs . Eko Tri Rahardjo ABSTRAK ketrampilan yang dapat dimanfaatkan untuk mencari tambahan pendapatan bagi masyarakat di daerah padat penduduk di Jakarta Timur dengan membuat berbagai barang keraj. Jurnal Sarwahita, 13, 126-131. https://doi.org/10.21009/sarwahita.132.08

Raharjo, T. (2011). Seni Kriya dan Seni Kerajinan.

Sumanto. (2011). Pendidikan Senirupa di Sekolah Dasar. Malang: FIP Universitas Negeri Malang.

Sumanto, \& Sukamti. (2018). Keragaman Jenis Dan Model Produk Home Industry. Sekolah Dasar: Kajian Teori Dan Praktik Pendidikan, 8285, 49-58. https://doi.org/10.17977/um009v27i12018p049

Suwardi, A. B., \& Saumi, F. (2018). Inovasi Produk Kerajinan Limbah Kelapa Sawit Menggunakan Teknologi Ramah Lingkungan ( Coconut Palm Waste Product Innovation by Using Eco Friendly Technology ). Jurnal Ilmiah Pengabdian Kepada Masyarakat, 4(1). journal.ipb.ac.id 